University of Nebraska - Lincoln

DigitalCommons@University of Nebraska - Lincoln

Textile Society of America Symposium

Proceedings

2020

Transformative Power of Stitchery: Sashiko from Cold Regions of Japan and Embroidery Work of the Nui Project

Yoshiko Iwamoto Wada

Follow this and additional works at: https://digitalcommons.unl.edu/tsaconf

Digitadrt of the Art and Materials Conservation Commons, Art Practice Commons, Fashion Design

Commens, Fiber, Textile, and Weaving Arts Commons, Fine Arts Commons, and the Museum Studies

detwerkns

Logo

This Article is brought to you for free and open access by the Textile Society of America at

DigitalCommons@University of Nebraska - Lincoln. It has been accepted for inclusion in Textile Society of America

Symposium Proceedings by an authorized administrator of DigitalCommons@University of Nebraska - Lincoln. 
Published in Hidden Stories/Human Lives: Proceedings of the Textile Society of America 17th Biennial Symposium, October 15-17, 2020. https://digitalcommons.unl.edu/tsaconf/ Copyright @ 2020 Yoshiko Iwamoto Wada doi: 10.32873/unl.dc.tsasp.0106

\section{Transformative Power of Stitchery: Sashiko from Cold Regions of Japan and Embroidery Work of the Nui Project \\ Yoshiko Iwamoto Wada \\ yiw@yoshikowada.com}

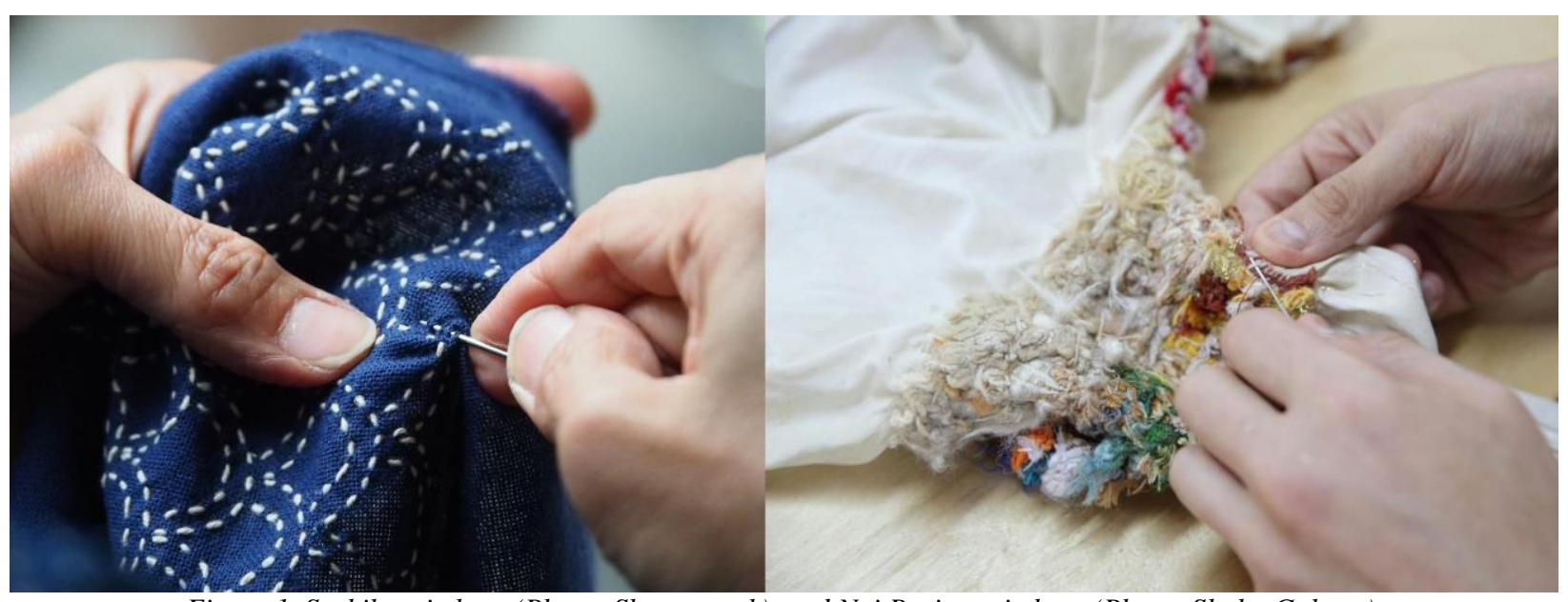

Figure 1. Sashiko stitchery (Photo: Shutterstock) and Nui Project stitchery (Photo: Shobu Gakuen).

\section{INTRODUCTION}

Anthropologist Tim Ingold, in his talk at an international conference in 2012, considered the Eurocentric mode of "Making Through Thinking" a dead-end. ${ }^{1}$ This mode of thinking is rooted in Aristotle's philosophy of Hylomorphism (from the Greek words hyle, "matter," and morphe, "form") in which a maker projects an idea of an object and shapes the matter to follow the idea. ${ }^{2}$ Instead, Ingold argues that creativity flows when makers join with the movements of materials and awareness, feeling their way ahead in real time. This joining with the forward movement of making and feeling is essentially a process of improvisation, finding one's way in what Ingold calls "thinking-through-making."

In this paper, I will discuss the evidence for this process in two textile practices from Japan: the improvisational stitchery of the Nui Project craft studio of developmentally challenged adults and the folk tradition of sashiko (Figure One). To understand stitchery, which is one of the most enduring technologies humans have utilized, I will start by considering a prehistoric needle and the way stitchers might have interacted with it when threaded. By moving a threaded needle through cloth, humans can join, mend, strengthen, shape, and ornament clothing and other items and also unintentionally or intentionally create works of art. The members of the Nui Project stitching studio at Shobu Gakuen, a social welfare organization that serves differently abled

\footnotetext{
${ }^{1}$ Ingold, "Thinking through Making," Tales from the North, 2012 conference at the Sámi Cultural Centre in Inari, Finland, April 10-12, 2012; video posted by Pohjoisen kulttuuri-instituutti - Institute for Northern Culture, a Lapland University Consortium on October 31, 2013, https://www.youtube.com/watch?v=Ygne72-4zyo.

${ }^{2}$ Ingold, Making: Anthropology, archaeology, art and architecture (Oxon: Routledge, 2013), $20-21$.
} 
adults, focus on the essential action of needle movement and make thread patterns free from complex social factors. The stitchers have no association with conventional stitchery craft nor do they have particular goals. I shall argue that observing their process raises awareness of modes of thinking-through-making and feeling-though-doing in craft practices.

The second example is sashiko, folk textiles worn by the people who made them or by their family members, reflecting the currents of lives and carrying social, regional, and cultural iconography and styles. The textiles are constantly connected with people through a process of utility, recording their daily activities by wear, tear, soil and dirt and through being darned and reinforced to perpetuate their usefulness. Textile takes on a life parallel to that of the people who make and use it. In this context, textile continues to live until it is dissolved to dust. This paper argues that the stitchery process and the needle's agency, transform materials and connect stitchers with their time and place and the circumstances of daily life.

\section{TECHNOLOGY}

Stitchery may well be one of the earliest textile technologies homo sapiens and their ancestors invented in response to what nature afforded them for survival. Since ancient times, before weaving was invented, ${ }^{3}$ pre-humans and humans might have created essential, utilitarian 3D objects by joining hides, skins, and bark, all of which are pliable 2D planes. Fingers may have done the work of knotting/ binding/ cinching and, eventually, of making a hole with a sharp tool through which a strip of plant matter or sinew was pushed to interlace planes. When was a more suitable tool, the needle, invented?

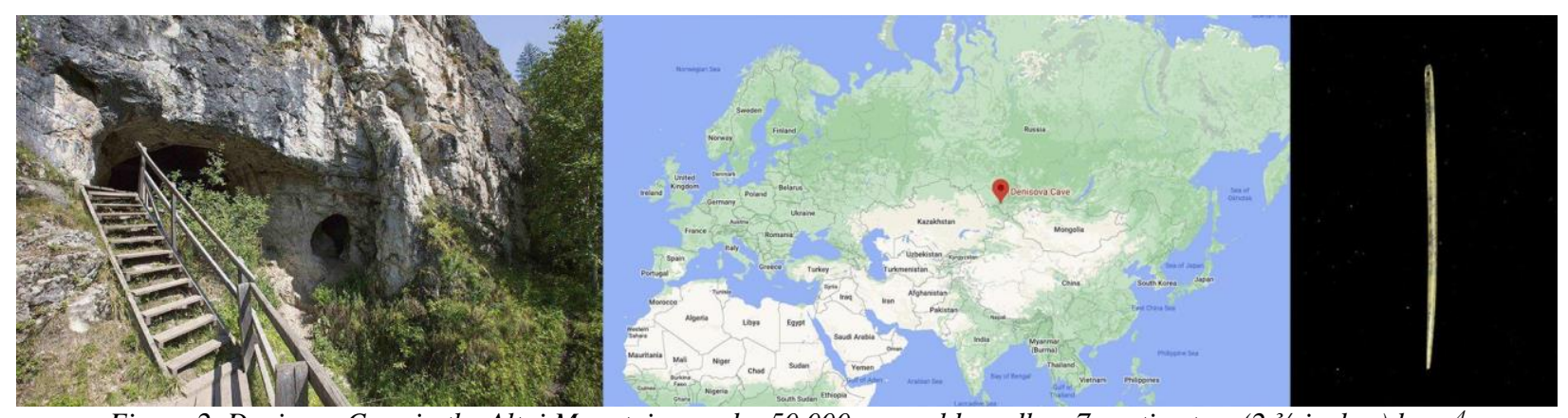

Figure 2. Denisova Cave in the Altai Mountains, and a 50,000-year-old needle - 7 centimeters (2 3/4 inches) long. ${ }^{4}$ (Photo: Vera Salnitskaya.)

In 2016, Russian archeologists reported the finding of a 50,000-year-old needle -7 centimeters ( $23 / 4$ inches) long and fashioned from a bone of an unidentified large bird - in Denisova Cave in the Altai Mountains (Figure Two). This discovery indicates that early hominids and homo sapiens evolved by working with what nature afforded them. Psychologist James Gibson's theory of affordances proposes that creatures respond to and adapt that which the environment

\footnotetext{
${ }^{3}$ Margarita Gleba and Ulla Mannering, eds., Textiles and Textile Production in Europe from Prehistory to AD 400 (Barnsley: Oxbow Books, 2016), 402.

${ }^{4}$ In the Tuesday, August 23, 2016 Archaeology section of the Siberian Times a reporter quoted Dr. Maksim Kozlikin, head of the excavations at Denisova Cave: "It is the longest needle found in Denisova Cave." Professor Mikhail Shunkov, head of the Institute of Archaeology and Ethnography in Novosibirsk, was responsible for the excavation project.
} 
provides, whether for good or ill. ${ }^{5}$ From the evidence, we may assume that some Denisovans found a bone and pierced a hole for thread, which afforded them the possibility to stitch together two planar pieces to make an object. The persistence of such a simple tool for over 50,000 years, keeping its original form and function, if not its early material and production method, demonstrates how essential the needle is to textile material culture. As David Morgan explains:

If culture is the full range of thoughts, feelings, objects, words, and practices that human beings use to construct and maintain the life-worlds [sic] in which they exist, material culture is any aspect of that world-making activity that happens in material form. ${ }^{6}$

A simple tool, the needle has contributed to many aspects of world-making, allowing stitchery with a mesmerizing array of threads from simple hemp to luxurious silk, rustic wool to gold, and even sutures in surgery. It has served the needs of rich and poor, including the members of the Nui Project.

\section{THE NUI PROJECT}

The Shobu Gakuen Social Welfare Facility (Shobu means iris, the plant, and Gakuen means school) cares for developmentally challenged adults in Kagoshima, the city at the southern tip of Kyushu Island. It was established in 1973 by the parents of its director, Shin Fukumori, and has earned its reputation as an anomaly. Unlike conventional institutional facilities, the architecture and landscape are designed organically, including a pond, pens for animals, and no straight hallways or pathways. Visitors to the Gakuen notice that there is no hierarchy among Gakuen members, staff, and managers and come away saying it is the happiest place they have visited. ${ }^{7}$ The program offers activities that connect participants with the "normal" society outside the facility and is celebrated for its successful outcomes by social workers, families of its participants, and mental health specialists. ${ }^{8}$ In English, Nui Project means Stitching Project. Nui is an adjective form of the Japanese verb $n u u$, to stitch or to sew. ${ }^{9}$ Moving a threaded needle through cloth is the main action performed by the differently abled members of the project, using cloth or blank shirts with threads of their choice. ${ }^{10}$

\footnotetext{
${ }^{5}$ James J. Gibson, The Ecological Approach to Visual Perception, Classic Edition (New York \& London: Psychology Press, 2015), 119-20.

${ }^{6}$ David Morgan, "The Materiality of Cultural Construction," Material Religion 4, no. 2 (2008), 228-29.

${ }^{7}$ Fukumori, 40-41.

${ }^{8}$ Fukumori, 82-84.

${ }^{9}$ Yasuo Kitamura, et al., eds., Nihon Kokugo Daijiten, Second Edition (Tokyo: Shogakukan Inc., 2000-03), s.v. nui, nominalization of $n u u$.

${ }^{10}$ Author's firsthand observation from several visits at Shobu Gakuen between 1999 and 2017.
} 


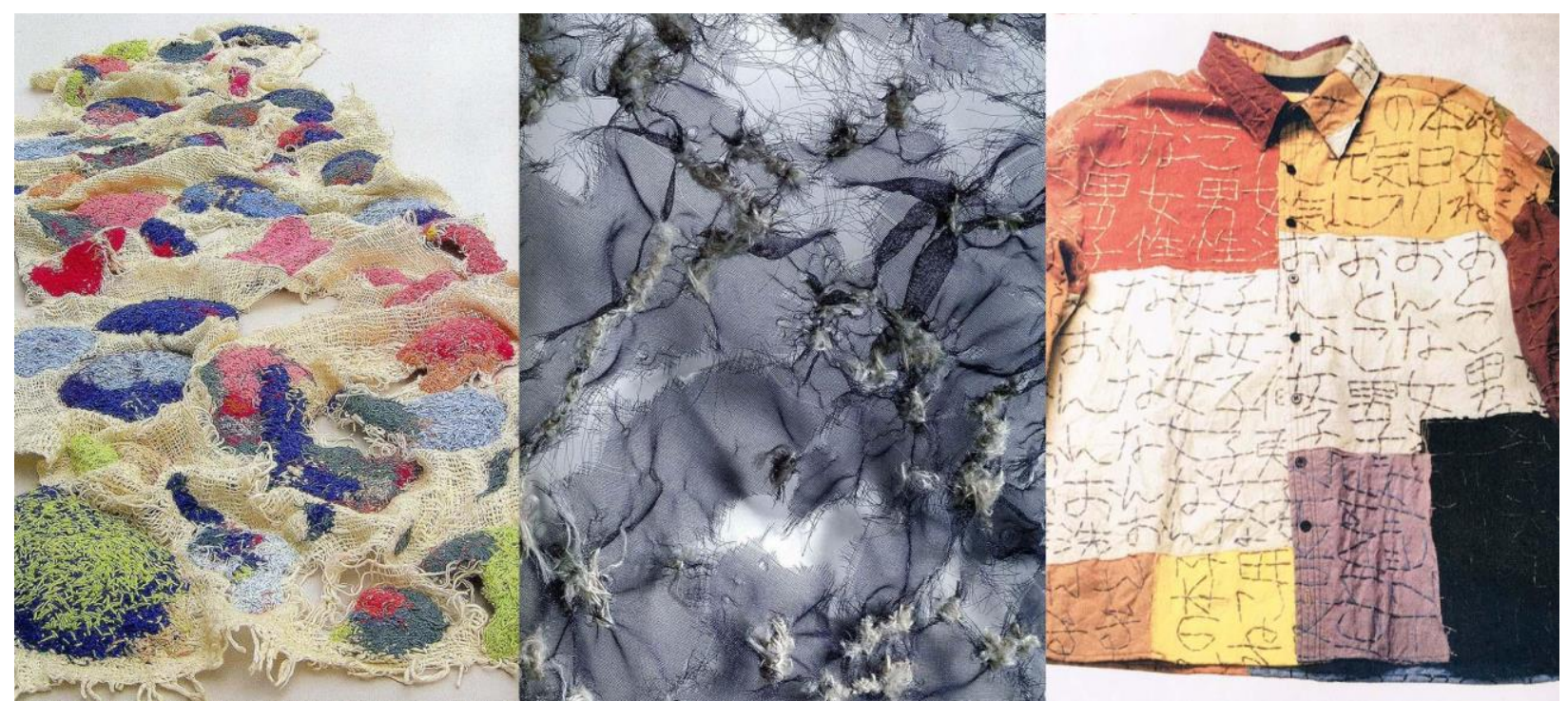

Figure 3. Nui Project stitchers' work (Photo: Shobu Gakuen).

The needle, which opened a door to a long string of inventions and cultural phenomena in textile making over several decamillennia, plays an important role in the lives of the participating members of Shobu Gakuen's Nui Project studio. ${ }^{11}$ A threaded needle affords the members to express their experience of life - the ticking of time, feeling, seeing, imagining, and responding to wherever the process and materials may take them. Adapting Ingold's concept of "thinkingthrough-making," their creative process might be described as a process of "feeling-throughdoing" (Figure Three). Unlike the conventional creative process that Ingold refers to, Nui Project stitchers are entirely absorbed in their process and have no intention of making an end product or expecting an accolade for their artistic accomplishment. ${ }^{12}$

Richard Sennet, author of The Craftsman, writes in the section on Material Consciousness that when a craftsman does not separate understanding [thinking] from doing and "engage[s] in a continual dialogue with materials,... [h] is or her arousal is more complete." 13 I understand "arousal" to be a state in which materials and makers connect and flow through the process. As in the craftsman's process that Sennet describes, the Nui Project stitchers, without separating thinking and doing, simply respond to what the needle and cloth afford them. They become one with the materiality of textile and do stitchery in the moment, using hands, eyes, a threaded needle, and cloth, nothing more. Fukumori describes Shobu Gakuen as arinomama no aru tokoro. ${ }^{14}$ According to him, this means the place where things and people are accepted as they are with no expectation for them to follow conventional rules. The expression "arinomama" may be associated with the Mingei theory of Sōetsu Yanagi who described folk craft objects as "being born, not made." Thus their beauty is formed by "employing man's first tools, his own hands, for the expression of his inner nature."15

\footnotetext{
${ }^{11}$ Shobu Gakuen website: https://www. shobustyle.com/new-page-1

${ }^{12}$ Fukumori, 78 and 127.

${ }^{13}$ Richard Sennet, The Craftsman (New Haven \& London, Yale University Press, 2008), 125.

${ }^{14}$ Fukumori, 32-44.

${ }^{15}$ Sōetsu Yanagi, The Unknown Craftsman: A Japanese Insight into Beauty (Tokyo: Kodansha International, 1989), 88.
} 
Fukumori was inspired by Mingei ideas and in 1985 began incorporating craft-related activities for Gakuen members around the campus. First woodworking, and eventually, along with the Nui Project, he introduced pottery, paper making, painting, a bakery, soba noodle shop, cafe, and percussion music band. New members are given opportunities to try out various activities; however, if they encounter an activity they feel comfortable with, their desire to join the studio without further exploration is accepted. Unlike ordinary people in a decision making process, they do not wish to try out all the alternatives, to compare and decide which is most suitable or desirable. ${ }^{16}$ Upon joining a studio, they generally wait for guidance, however, they are usually left alone to become familiar with the studio's activity. Without any instructions, they begin to intuitively follow the materials, tools, and flow of process to find their own expression. Gallerists and curators of Art Brut who praise the objects made by the Gakuen members present them as art. ${ }^{17}$ Staff turn the members' creations into bags, shirts, tapestries, or art objects to exhibit or use for fundraising. The stitchers hardly show attachment to what they created; they simply enjoy the stitching or "doing."

Understanding James Gibson's theory of affordances, mentioned earlier, changed Fukumori's mode of thinking from having the members conform to the behavioral conventions of normal society to providing facilities, activities, and care that afford Gakuen members to respond in a manner close to their reality. ${ }^{18}$ Fukumori attributes his mind shift and decision to redesign the facility to encountering Gibson's theory of affordances, as translated and annotated by Masato Sasaki in his book titled Introduction to Affordances, ${ }^{19}$ which refers to all actions by humans based on their physical or mental capabilities as responses to the possibilities and limitations found within an object or environment. Nui Project stitchers are engrossed in the process of corresponding with the materials and a needle, which gives them agency and infuses the textile with their attitudes and experienced reality.

\section{SASHIKO}

Although archaeologists have not found a needle used by early people on the Japanese archipelago, one can assume that as long as woven textiles existed in Japan, people stitched and darned to optimize material's potential. Sashiko, the second subject of this paper, is based on using a needle and pieces of cloth to sustain the functionality of textiles required for people's daily lives. Through literature, prints, museum collections, and etymology, we can glimpse the life of commoners who utilized the folk tradition of sashiko, which came to be actively practiced across Japan in the past few hundred years. In this stitchery practice, a threaded needle becomes the co-agent with a human, infusing the properties of materials in a "processual" and relational manner, interweaving the stitched textiles with the lives of its maker and wearer.

The Japanese term "sashiko" comes from the verb sasu, which means to pierce something or someone. Stitching occurs when cloth is pierced with a threaded needle. Sashi is an adjective

\footnotetext{
${ }^{16}$ Fukumori, 97.

17 Fukumori, 129-139.

${ }^{18}$ Fukumori, 163-66.

${ }^{19}$ Masato Sasaki, Introduction to Affordances: Where the Intellectual Awareness Derives from (Tokyo: Kodansha Gakujutu Bunko, 2008), 72-74.
} 
form of sasu (刺す) 20 and since sashiko (刺し子) commonly ends with $k o$ (子), literally meaning a child, some Western sashiko practitioners erroneously interpret it as a diminutive form of sashi, thus translating it as "little stabs" or "little piercing." ${ }^{11}$ What $k o$ (子) actually means here is "thing" or "clothes." The word sashikoginu or sahikogino was phonetically written and appeared in documents in the 1780s and 90s, identifying clothing with geometric stitching patterns worn by locals in northeastern Japan ${ }^{22}$ (Figure Four).

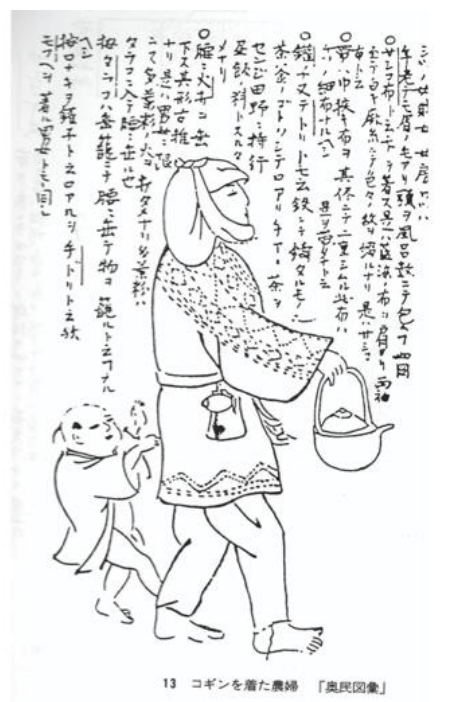

\section{Sashikoginu or Sashikogino and \\ Kogin or Kogin-zahi}

Figure 4. Sashiko no Kenkyū (Research on Sashiko) by Iku Tokunaga, 54 and 416.
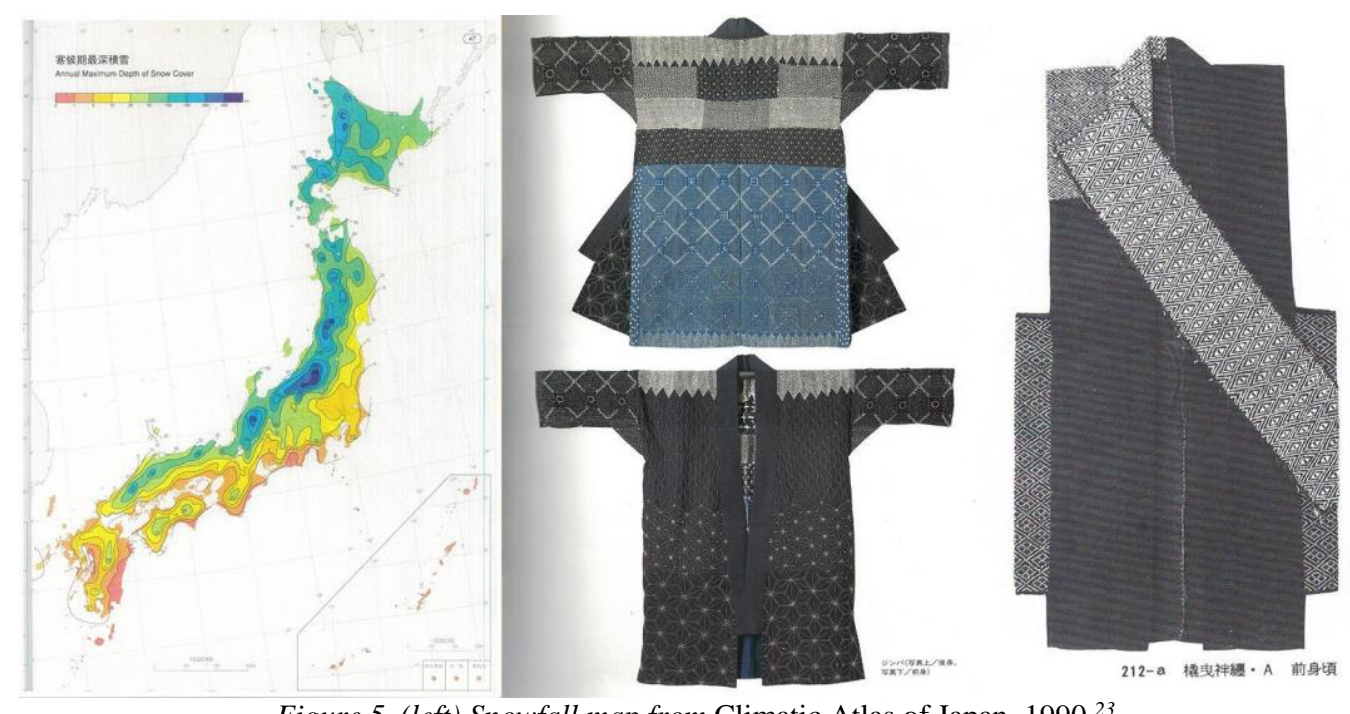

Figure 5. (left) Snowfall map from Climatic Atlas of Japan, 1990.23

(right) Sashiko noragi (farm work clothing), Sashiko no Kenkyū (Research on Sashiko) by Iku Tokunaga, 17 and 238.

\footnotetext{
${ }^{20}$ Yasuo Kitamura, et al., eds., Nihon Kokugo Daijiten, Second Edition (Tokyo: Shogakukan Inc., 2000-03), s.v. sashi, nominalization of sasu.

${ }^{21}$ Susan Briscoe, The Ultimate Sashiko Sourcebook: Patterns, Projects and Inspirations (Pynes Hill: David \& Charles Ltd., 2005), 6.

${ }^{22}$ Iku Tokunaga, Sashiko no Kenkyu (Research on Sashiko) (Tokyo: Iseikatu Kenkyukai, 1988), 22, 60-69.

23 Japan Meteorological Agency, Climatic Atlas of Japan, 1990 (Tokyo: Ministry of Finance, 1993).
} 
Sashiko tradition is commonly associated with Tōhoku, the northeastern region, known for its heavy snowfall and long winters (Figure Five). Its population used stitchery to reinforce and insulate their clothing and bedding to survive their harsh life with limited resources. ${ }^{24}$ In addition, sashiko stitchery practice has been found around the Japanese archipelago beyond the northeastern regions, as indicated in a map showing a wide range of sashiko and sakiori (ragweave) practices that are largely connected to the cotton rag trade (Figure Six). ${ }^{25}$ When cotton cultivation became established in the 16th to 17th century in warmer regions, worn-out cotton clothing and rags, along with small amounts of precious new cotton yarns and cloth, became important trade commodities transported to the regions where cotton did not grow. This rag trade connected urban centers, where populations had more means, or areas near cotton growing or weaving centers, to seaports and remote fishing villages on islands and coastal regions. ${ }^{26}$ Cotton, the new miracle fiber, was made available to less affluent populations; and until mid-twentieth century sashiko practice became more intensive, as people capitalized on the potentials of the material.

Japanese Society for the Science of Design

○印…中継港 Major Ports

Japan Sea

印…木綿の産地 Cotton Growing Areas

印…主要な裂き織りの産地 Sakiori Producing Areas

・印…木綿の交易地 Cotton Market Centers

Hokkaido Island

西迴り航路

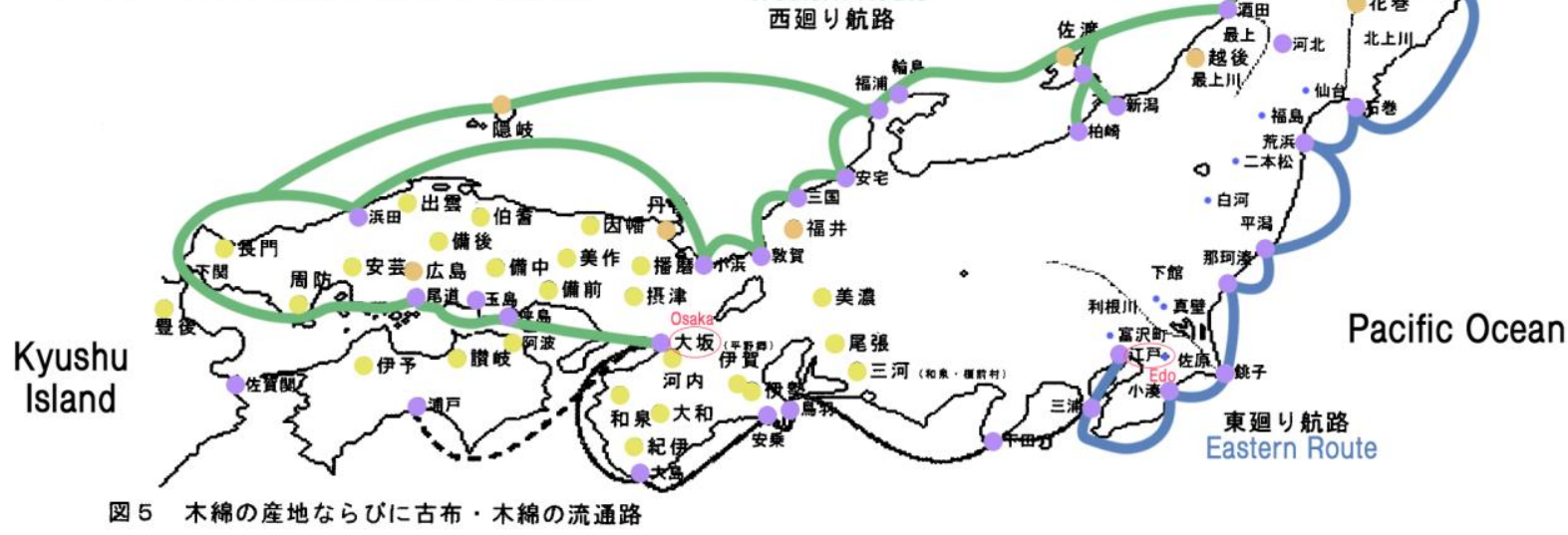

Figure 6. Map of cotton growing centers, shipping routes for cotton rag trade, cotton market center, and sakiori (rag weave) producing areas. "The System for Distribution of Old Cloth Used in the Resource Circulation Art of Rip Weaving," 58.

When cotton first became available, people began to use stronger and warmer cotton thread on locally woven bast fiber cloth. Soon, stitchers utilized precious cotton cloth in the making of utilitarian textiles such as jackets, pants, vests, and aprons, as well as leggings, ankle and heel

\footnotetext{
${ }^{24}$ Shin-Ichiro Yoshida and Dai Williams, Riches from Rags: Saki-ori and Other Recycling Traditions in Japanese Rural Clothing (San Francisco: Museum of Craft and Folk Art, 1994), 9-10.

25 Toshiki Matsumura, Donza: The Sashiko from the Sea (Fukuoka: Fukuoka City Museum, 2005), 12.

${ }^{26}$ Kōhei Ōtsuka, et al., "The System for Distribution of Old Cloth Used in the Resource Circulation Art of Rip Weaving," Bulletin of JSSD 50, no. 2, 53-62 (Japanese Society for the Science of Design, 2003), 56-58.
} 
covers, and split toe socks. For protecting hands and arms from the cold and from the rigors of farm labor, they stitched arm and wrist covers, palm and hand covers, and grip protectors (Figure Seven). ${ }^{27}$ Indeed, with a threaded needle as co-agent, a stitcher infused the properties of materials with reinforcement and repair, regenerating textile articles which lived with the users, recording the demanding currents of daily life. ${ }^{28}$ The stitchery preserved the functionality of the textile and imbued the material with resilience and strength.
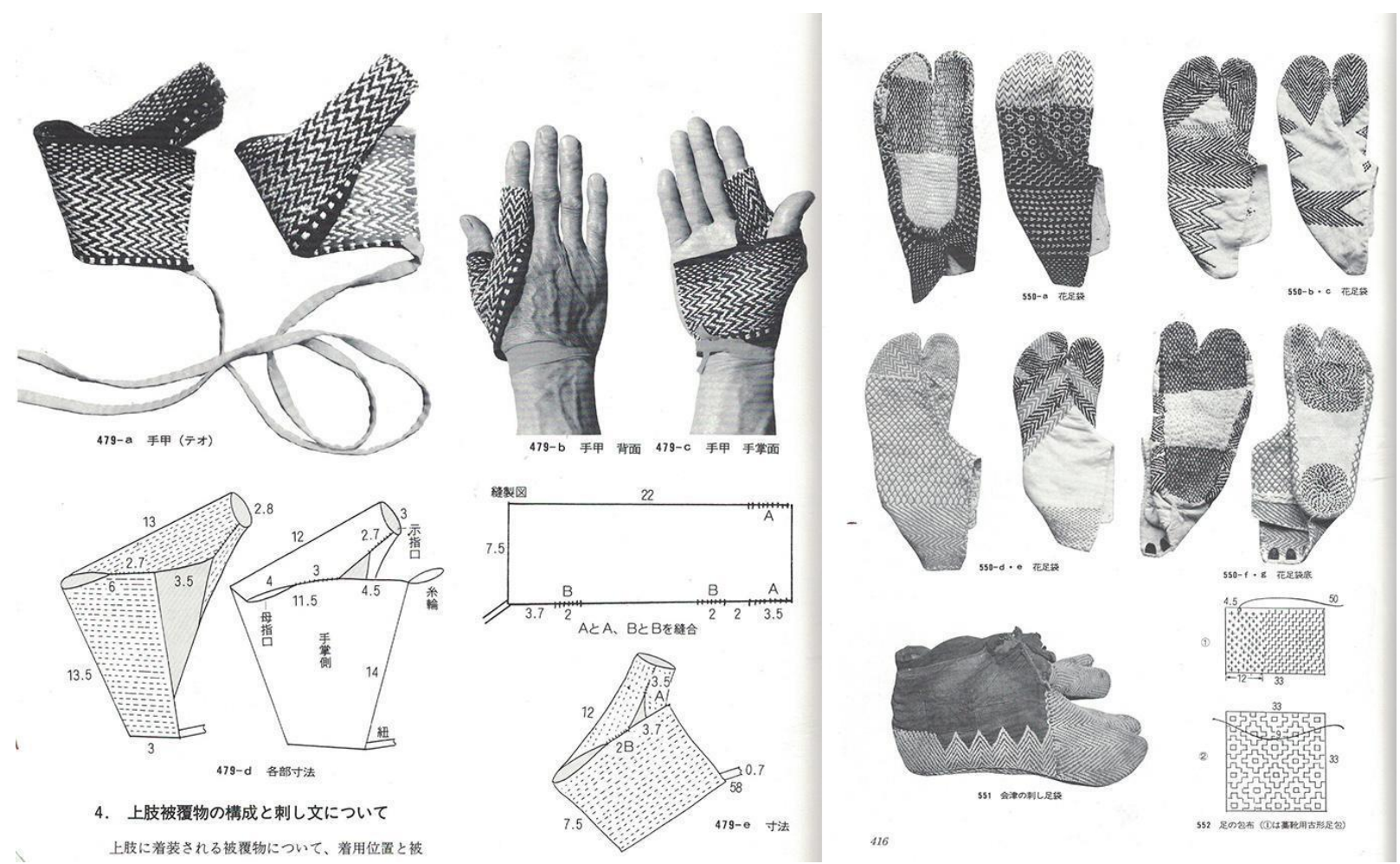

4. 上肢被覆物の構成と刺し文について

上肢に着装される被覆物について、着用位䡩と被

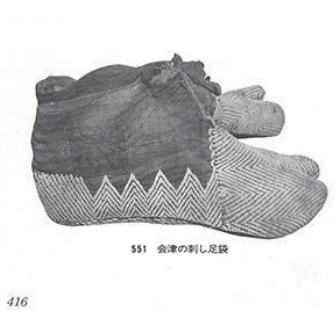

Figure 7. Sashiko no Kenkyū (Research on Sashiko), 382 and 416.

Discussion of regional aesthetic styles, techniques, and patterns of sashiko is not within the scope of this paper, but the following examples - donza and Harakata sashiko - will illuminate the diversity of this folk tradition (Figure Nine and Ten). Fishermen's clothing, donza, its wide distribution (Figure Eight) and extensive use of sashiko stitchery, was brought to public attention by the 2005 exhibition in Fukuoka on the southern island of Kyushu. ${ }^{29}$ This group of folk textiles was not studied previously except ones from Awaji Island. ${ }^{30}$

\footnotetext{
${ }^{27}$ Iku Tokunaga, Sashiko no Kenkyu (Research on Sashiko) (Tokyo: Iseikatu Kenkyukai, 1988), $377-424$.

${ }^{28}$ Ingold, "Materials against materiality," Archaeological Dialogues 14, no. 1 (Cambridge: Cambridge University Press, 2007), 1.

${ }^{29}$ Matsumura, 103.

${ }^{30}$ Sharon S. Takeda and Luke Roberts, Japanese Fishermen's Coats from Awaji Island (Los Angeles: The Fowler Museum \& University of California at Los Angeles, 2001).
} 


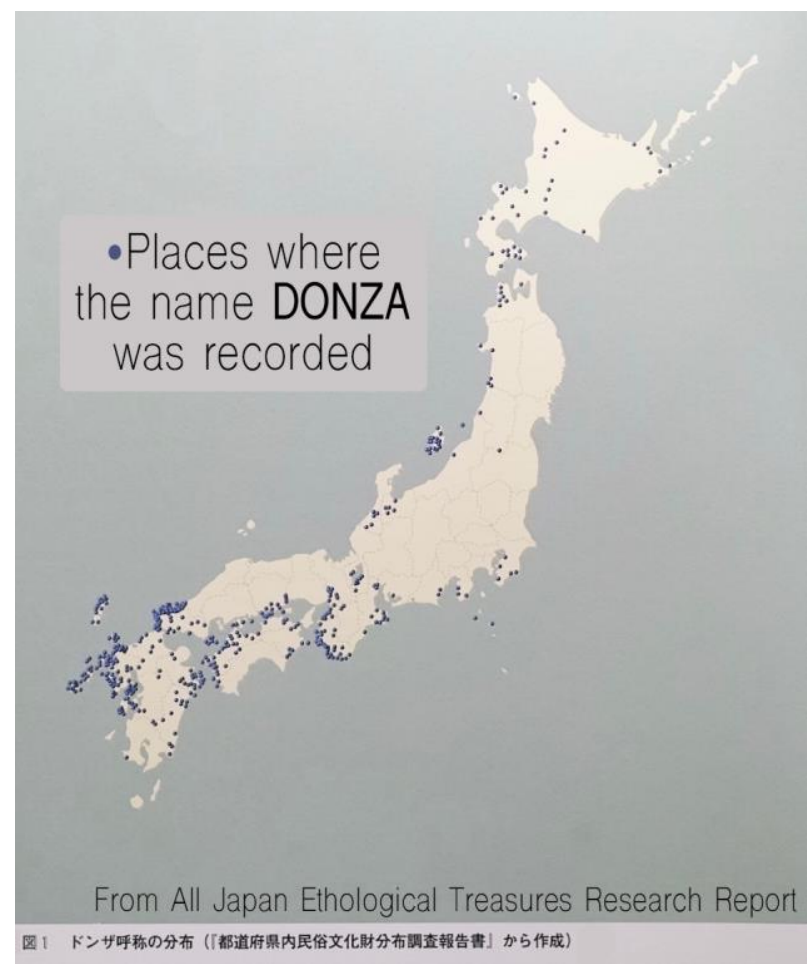

Figure 8. Map of places where the name Donza was recorded. Images from the Fukuoka City Museum exhibition catalogue, Donza: The Sashiko from the Sea.

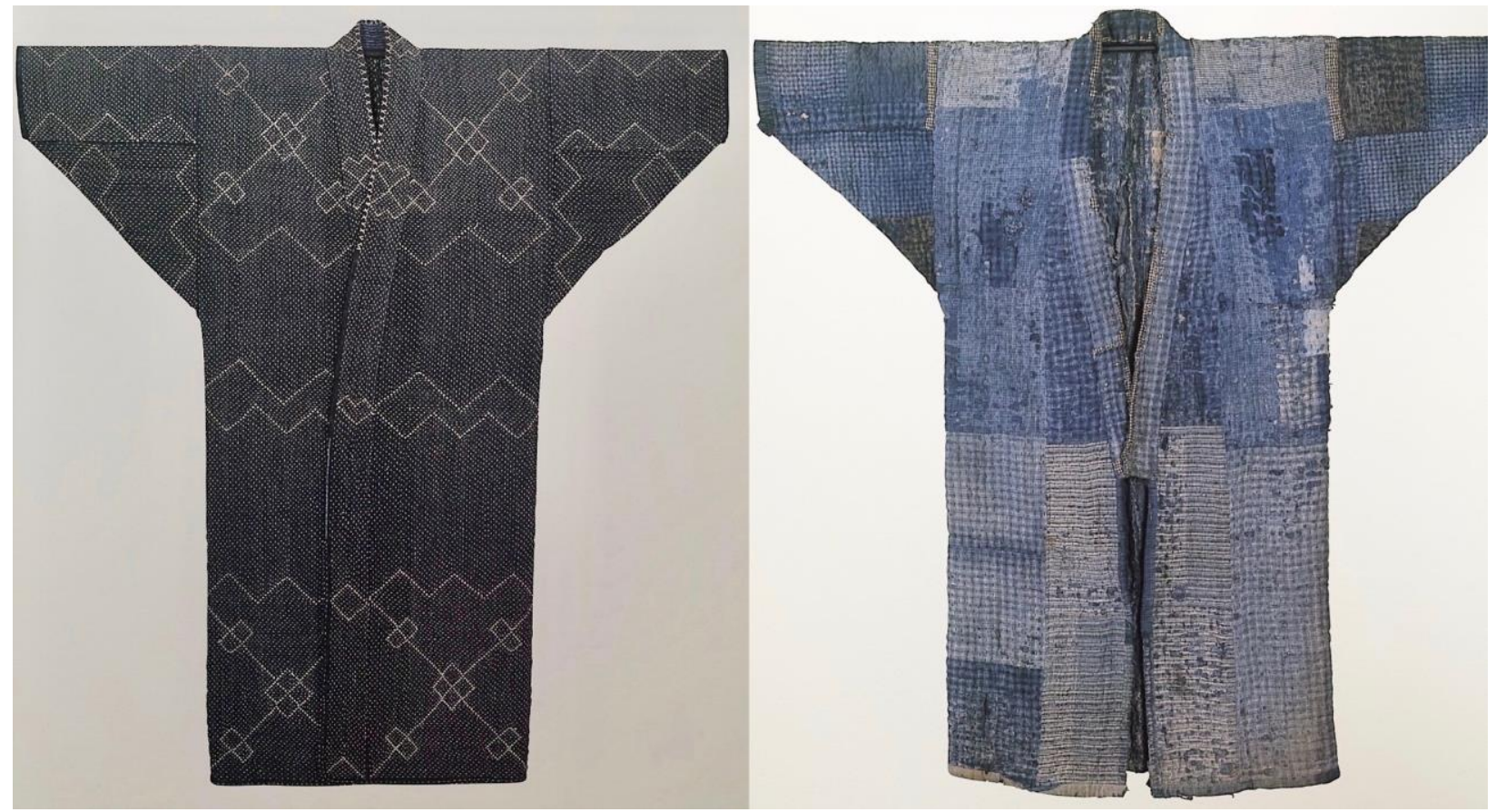

Figure 9. Donza for special occasions. Boro Donza for everyday use. Images from the Fukuoka City Museum exhibition catalogue, Donza: The Sashiko from the Sea.

The donza on the left is for special occasions; the one on the right for daily use shows mended wear and tear which would be referred to as boro (rag) donza because of its tatters and repairs. The donza (left) from Fukuoka on the southern island of Kyūshū shows an all-over large pattern 
laid out on the entire garment - a technical feat with sophisticated design. This may have been worn by a captain of a fishing boat when he appeared at festive occasions and landed at seaports for trading the catch, displaying a distinct local style as well as his leadership position. ${ }^{31}$

Aesthetic features of sashiko patterns in the southern islands differ from those in some islands in the north and from those made inland. The regional styles clearly demonstrate how hand craft is rooted in widely varied folklife across Japan.

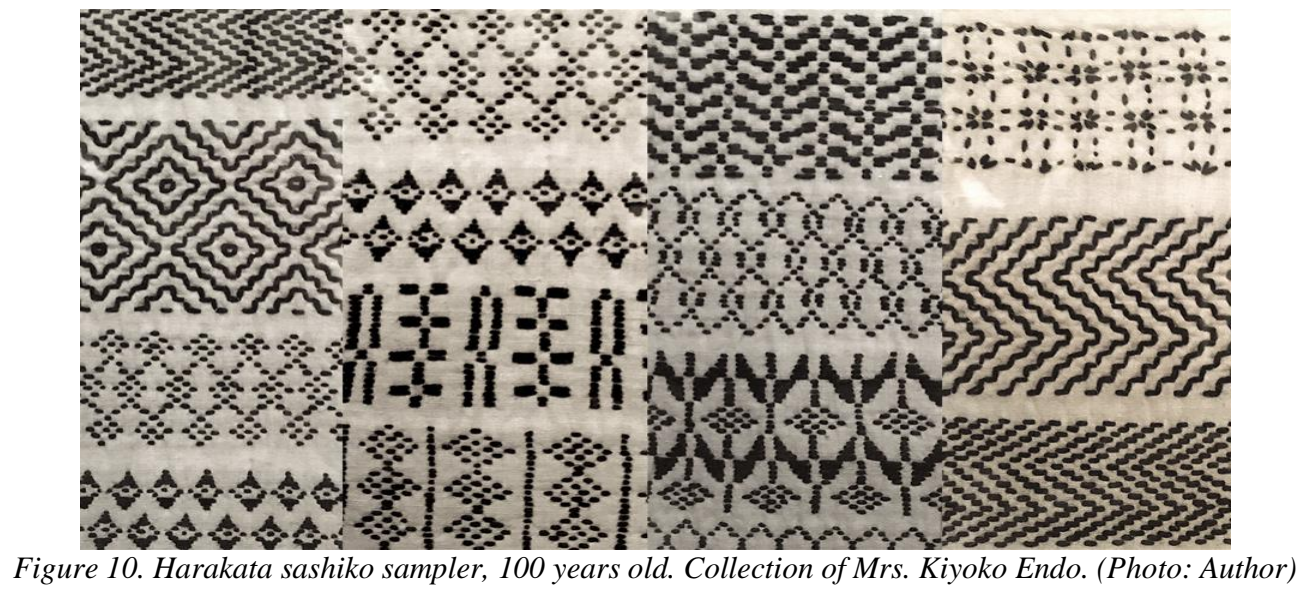

Another style of sashiko tradition is the Harakata sashiko in Yonezawa, a feudal castle town located in present-day Yamagata Prefecture, occupied by demoted Daimyo during the Edo Period (1603-1868). Low-ranking samurai, impoverished by drastic decrease of the fiefdom, had to practice farming on the side to feed their families. The proud and resourceful warrior-class women wove cloth for trade and developed an extensive sashiko practice to mend, reinforce, and sustain the life of their cloth and clothing (Figure Eleven). They lived in the Harakata district where they developed a distinctive urban style of sashiko. ${ }^{32}$ This is only one of many stories embedded in sashiko textile traditions.

\section{STITCHERY TRANSFORMATIONS}

Until recently, sashiko stitchery was primarily functional - the act of reinforcing and mending extended and sustained the life of cloth as part of people's lifeworld-making activity. For the Shobu Gakuen's Nui Project members, stitchery is an activity that sustains wellbeing in their daily lives. Both cases illustrate what Ingold describes as "forms of things [that] are continually generated and dissolved within the fluxes of materials across the interfaces between substances and the medium that surrounds them.." ${ }^{33} \mathrm{~A}$ threaded needle provides agency for negotiating between substances and the medium that surrounds textile and people.

To understand these textiles, the empirical nature of stitchery requires further analysis. A needle is a stick with a sharp point and an eye that affords thread to go through a planar surface, cloth or hide repeatedly and easily with precision. The needle functions as an extension of fingers

\footnotetext{
${ }^{31}$ Matsumura, 11.

${ }^{32}$ Oral interview with Mrs. Kiyoko Endō of Harakata in October, 2017. Mrs. Endō teaches and creates sashiko in the city of Yonezawa.

${ }^{33}$ Ingold, "Materials against materiality," 1.
} 
responding to thread. By the Upper Paleolithic Age, archaeological finds show evidence of two fibers twisted in opposite directions, $\mathrm{S}$ and $\mathrm{Z},{ }^{34}$ establishing a binary system and utilizing the tension to make a string or rope. ${ }^{35}$ This utilization of the binary system led to enormous possibilities for expanding textile technology over decamillennia, including making thread and a needle which led to the useful and versatile ancient running stitch. Cloth is a substrate made of a grid structure of warp and weft interlacing up and down - a binary system. Stitchers respond to the woven grid as well as to the up and down of dotted lines of stitching, in some cases overlaying thread in the substrate to add what functions as another weft by a counted-thread method. This system provides a foundation for endless possibilities to create geometric patterns that are functional and pleasing to the eye. They need no pre-registered design on the cloth to follow; the work is guided by the binary stitching on the woven grid, which yields an innate geometry that is visually grounded and powerful.

A quintessential example of art guided by a binary system is found in the weaving and drawing of Anni Albers. In an essay titled "Design: Anonymous and Timeless" she states:

Above all, the craftsman was free to follow the promptings of material, of color, line, texture: to pursue a thoughtful forecast of function, a cleverly conceived construction, to wherever it would lead him. The results were objects embodying the many forces that took part in their making. ${ }^{36}$

Albers, like Sennet, describes where and how the transformation takes place in craft through a process that embraces hands, eyes, materials and tools. This transformative process is illuminated by the material properties of textiles discussed in this paper that are created in a manner "processual" and physical, relational and living.

\section{CONCLUSION}

Sashiko craft has gone through transformations in modern Japan and recently became popularized internationally as an embroidery craft, rendering geometric or figurative patterns of running stitches, typically on a contrasting colored background using Japanese-style designs. Such changes resulted from the loss of sashiko's original purpose and cultural meaning as living conditions dramatically improved across the archipelago with Japan's postwar economic recovery. Subsequently, in the past several decades in Japan, sashiko became a craft sustained by small regional groups of dedicated women, hobbyists without cultural ties to the tradition, and artists worldwide using it for contemporary creative expression. ${ }^{37}$ Although stitchery, which was so central to the daily life of women in Japan for centuries, has lost its viability and vitality, people still perform Hari Kuyō (memorial for broken sewing needles) ${ }^{38}$ at temples on a certain

\footnotetext{
${ }^{34}$ Irene Emery, The Primary Structures of Fabrics: An Illustrated Classification (Washington, DC: The Textile Museum, 1994), 11.

${ }^{35}$ Elizabeth J.W. Barber, Women's Work: The First 20,000 Years (New York: Norton Paperback, 1995), 43-45.

${ }^{36}$ Anni Albers, Anni Albers Selected Writings in Design (Middletown: Wesleyan University Press, 2000), 37.

${ }^{37}$ Susan Briscoe, The Ultimate Sashiko Sourcebook: Patterns, Projects and Inspirations (Pynes Hill: David \& Charles Ltd., 2005), 15.

${ }^{38}$ Angelika Kretschmer, "Mortuary Rites for Inanimate Objects: The Case for Hari Kuyō," Japanese Journal of Religious Studies, 27, no. 3-4 (Fall 2000), 379-404.
} 
day of the year, sticking broken needles in a soft object such as tofu as a resting place and thanking them for their hard work. As Sennet states in Material Consciousness: Virtue Discovered in the Material, "the attribution of human virtue into materials is to heighten our consciousness of the materials themselves and in this way to think about their value." 39 The needle-memorializing ceremony suggests that Japanese people still recognize the importance of needles and stitching, despite the shifting currents of their lifeworlds. Sashiko stitchers whose lives depended on their work of sustaining textiles are no more. In 21st century society, where people's lives are filled with mass-produced, machine-made materials, sashiko practice has become separated from lifeworld-making activities and lost its involvement with people and their surroundings. The needle, after fifty thousand years of agency, has lost much of its power to transform except as part of industrial machinery that serves mass textile consumption. In the case of the Nui Project stitchers, however, because each of their lives is contained within a unique individual sphere, threaded needles in their hands can still empower materials and the stitchers' lives, telling stories and adding new dimensions to textile material culture.

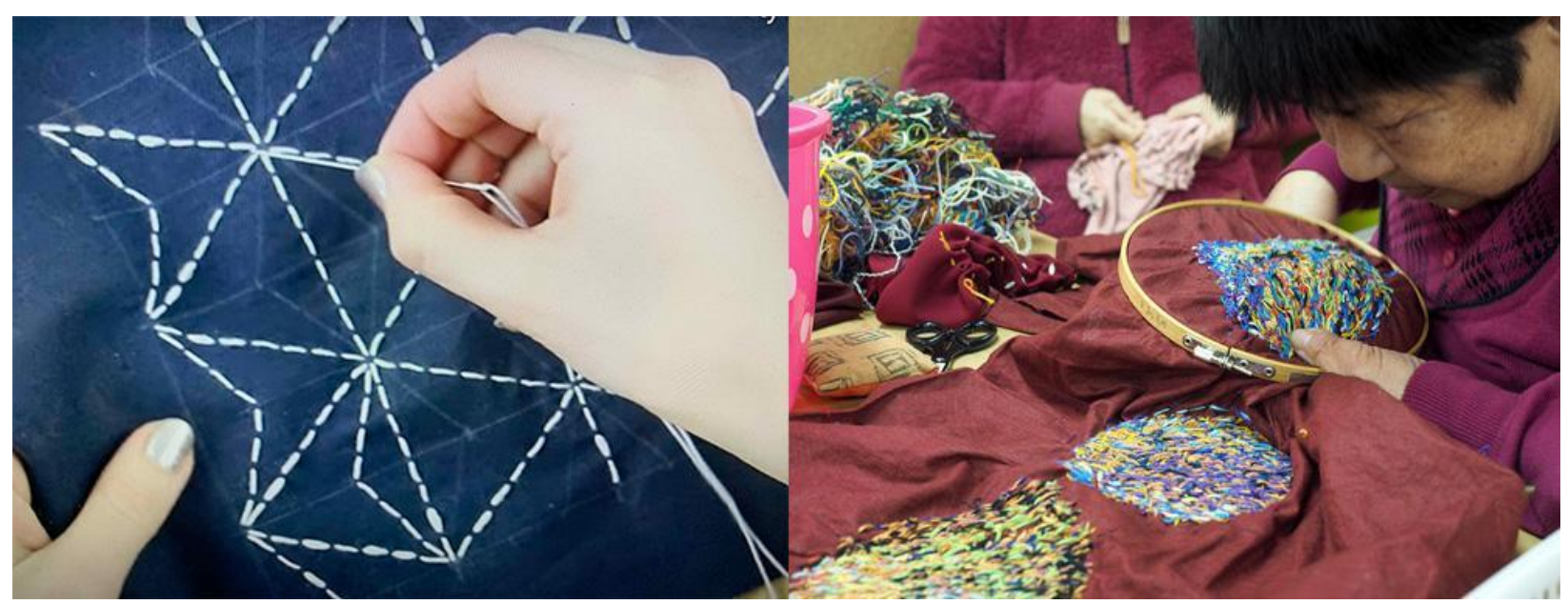

Figure 11. Sashiko stitchery (Photo: craftiosity.co.uk) and Nui Project stitchery (Photo: Shobu Gakuen).

\section{Bibliography}

Albers, Anni. Ed. by Brenda Danilowitz. Anni Albers Selected Writings in Design. Middletown: Wesleyan University Press, 2000.

Barber, Elizabeth J.W. Prehistoric Textiles: The development of cloth in the Neolithic and Bronze Ages. Princeton: Princeton University Press, 1991.

Briscoe, Susan. The Ultimate Sashiko Sourcebook: Patterns, Projects, and Inspirations. Pynes Hill: David \& Charles Ltd., 2005.

Emery, Irene. The Primary Structures of Fabrics: An Illustrated Classification. Washington, DC: The Textile Museum, 1994.

Fukumori, Shin. Arino mama ga aru tokoro (The place where things and people are accepted as they are). Tokyo: Shobun-sha, 2019.

\footnotetext{
${ }^{39}$ Richard Sennet, "Material Consciousness: Virtue Discovered in the Material," in The Craftsman (New Haven \& London: Yale University Press, 2008), 137.
} 
Gibson, James J. The Ecological Approach to Visual Perception, Classic Edition. New York \& London: Psychology Press, 2015.

Gleba, Margarita and Ulla Mannering (eds.), Textiles and Textile Production in Europe from Prehistory to AD 400. Barnsley: Oxbow Books, 2016.

Ingold, Tim. Making: Anthropology, Archaeology, Art and Architecture. London \& New York: Routledge, 2013.

Ingold, Tim. “Materials against materiality,” Archaeological Dialogues 14, no. 1 (2007), 1-16.

Ingold, Tim. "Thinking through Making." Tales from the North, 2012 conference at the Sámi Cultural Centre in Inari, Finland, April 10-12, 2012; video posted by Pohjoisen kulttuuri-instituutti - Institute for Northern Culture, a Lapland University Consortium on October 31, 2013, https://www.youtube.com/watch?v=Ygne72-4zyo.

Japan Meteorological Agency. Climatic Atlas of Japan, 1990. Tokyo: Ministry of Finance, 1993.

Kretschmer, Angelika. "Mortuary Rites for Inanimate Objects: The Case for Hari Kuyō." Japanese Journal of Religious Studies 27, no. 3-4, (Fall, 2000), 379-404.

Matsumura, Toshiki. Donza: The Sashiko from the Sea. Fukuoka: Fukuoka City Museum, 2005.

Morgan, David. "The Materiality of Cultural Construction,” Material Religion 4, no. 2 (2008).

Ōtsuka, Kōhei, Akira Ueda, Kiyoshi Miyazaki, and Chan-il Park. "The System for Distribution of Old Cloth Used in the Resource Circulation Art of Rip Weaving," Bulletin of Japanese Society for the Science of Design 50, no. 2 (2003). 53-62.

Sasaki, Masato. Affordance Nyūmon (Introduction to Affordances: Where Intellectual Awareness Derives from). Tokyo: Kodansha Gakujutu Bunko, 2008.

Sennet, Richard. The Craftsman. New Haven \& London: Yale University Press, 2008.

Shobu Gakuen website. https://www.shobustyle.com/new-page-1 [Accessed January 23, 2021]

Siberian Times (Novosibirsk, Russia) August 23, 2016 in the Archaeology section.

Takeda, Sharon S. and Luke Roberts. Japanese Fishermen's Coats from Awaji Island. Los Angeles: The Fowler Museum and University of California at Los Angeles, 2001.

Tokunaga, Iku. Sashiko no Kenkyu (Research on Sashiko). Tokyo: Iseikatu Kenkyukai, 2013, 1989.

Yanagi, Sōetsu. The Unknown Craftsman: A Japanese Insight into Beauty. Tokyo: Kodansha International, 1989.

Yoshida, Shin-Ichiro, and Dai Williams. Riches from Rags: Saki-ori and Other Recycling Traditions in Japanese Rural Clothing. San Francisco: Museum of Craft and Folk Art, 1994. 